\title{
Earthquakes in the Skagerrak recorded at small distances
}

\author{
SØREN GREGERSEN
}

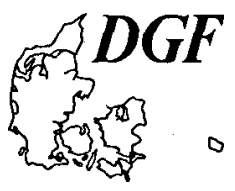

Gregersen, S.: Earthquakes in the Skagerrak recorded at small distances. Bull. Geol. Soc. Denmark, vol. 28, pp. 5-9, Copenhagen. October 23rd, 1979. https://doi.org/10.37570/bgsd-1979-28-02

\begin{abstract}
During the winter 1977-1978 up to 3 seismographs were temporarily situated in the northern part of Jutland with the aim of recording near earthquakes. 3 seismic events, presumably earthquakes, have been recorded by 1,2 or 3 of these seismographs. One of the earthquakes was large enough for a special investigation. The location of that earthquake is quite close to the coast of Jutland, while the two smaller earthquakes are located in the Norwegian Channel of the Skagerrak where a number of previous earthquakes are known to have happened. The depth of the largest earthquake is $40 \mathrm{~km}$. The depth estimate is more accurate than any previous estimate because of the near seismic stations, that recorded the earthquake.
\end{abstract}

Søren Gregersen, Geodetic Institute, Department of Seismology, Gamlehave Alle 22, 2920 Charlottenlund. November 30th, 1978

Several times each year an earthquake is reported to have happened in the Skagerrak. Usually only a few seismological stations record these earthquakes because the stations are located quite far away from the earthquakes and the earthquakes are small. With the purpose of recording some of these earthquakes 3 seismological stations were operated in the northern part of Jutland during the winter 1977-1978. All of the stations have been in abandoned limestone quarries. One was in Gøttrup just south of Fjerritslev. The two others were underground, in Mønsted and in Thingbæk (fig. 2). One of the instruments was for a short time operated in Horne near Hirtshals. It was soon moved because we realized that we would obtain less noisy records by moving the instrument from the loose soil at Horne to a more solid limestone foundation at Thingbæk. Not all of the stations have been in operation all winter, because of technical difficulties with the instruments.

On the 26th of April 1978 an earthquake in the Skagerrak was recorded by two of the seismographs in Jutland, in Gøttrup and in Mønsted, and by many seismographs at larger distances. The seismic record from the seismograph near Gottrup is presented in fig.1. Such a clear record of a near Danish earthquake is worth noticing. The instrument records vertical earth motion with a magnification af approcimately 40.000 for the frequencies of this signal: If one follows the trace of the pen in fig. 1 from the minute mark at 12 hours 32 minutes one sees that the pen moved only slightly for 52 seconds after the minute mark and then moved vigorously for more than a minute. Two types of waves can be distinguished on this record. A P wave begins at time $12^{\mathrm{h}} 32^{\mathrm{m}} 52^{\mathrm{s}}$. This lasts for a few seconds, and the pen motion is seen to decrease. 9 seconds after the $P$ wave arrival an $S$ wave is seen in the record. A time difference of only 9 seconds between these two wave types is unusual for observations in Denmark. It corresponds to a distance to the earthquake of only 70 kilometers. Longer time differences correspond to longer distances.

Based on seismic records from the surrounding countries the earthquake of APR 261978 has been located by the present author at a position closer to the coast of northern Jutland than most of the previous instrumentally located earthquakes in the Skagerrak (table 1, fig. 2). The seismogram readings have been compared for stations that recorded this earthquake in 1978 as well as an earthquake in 1969, which was located by the International Seismological Centre, ISC. Seismogram readings common for the two earthquakes are available at the stations in Copenhagen, Uppsala, Bergen and Moxa in East Germany. The locations based on this limited data, are one degree of longitude apart, the 1978 


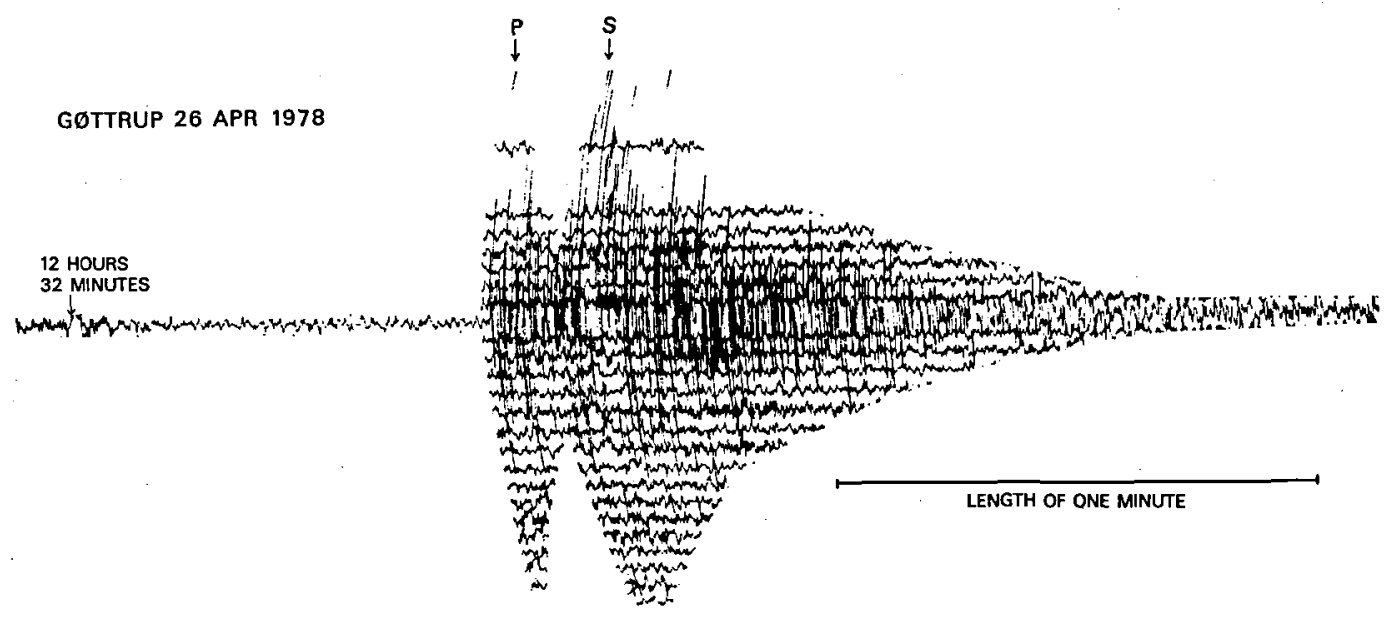

Figure 1. Seismogram from vertical seismograph ( $S-13$ seismometer and $M E Q-800$ recording) in northern Jutland. $P$ and $S$ waves are distinguished with a time difference of 9.0 seconds.

epicenter being approximately $50 \mathrm{~km}$ closer to the coast than the 1969 epicenter. The latter is coincident with a few other earthquake epicenters (fig. 2).

It was also interesting to compare the data of the earthquake APR 261978 with that of an earthquake OCT 18 1954, since the old estimate of the epicenter of the 1954 event was close to that of the 1978 event. The 1954 estimate was $56^{\circ} 44^{\prime} \mathrm{N} 08^{\circ} 24^{\prime} \mathrm{E}$, in northern Jutland. It was based on instrumental data from only four stations at distances between 300 and $1400 \mathrm{~km}$. Also taken into account was a report by Saxov (1956) with the macroseismic observations on where the earthquake was felt in northern Jutland. The time differences between the seismogram readings of the $S$ wave in Copenhagen and the $P$ and the $S$ waves in Uppsala are the same for the events in 1978 and in 1954. This indicates that the two events may be very close to each other.

Table 1. Earthquakes in the Skagerrak and along the Norwegian south coast. All ISC locations for the period $1964-1974$ and the locations calculated by the present author using a computer program HYPO 71 (Ward and Gregersen 1973) and an average crustal structure for Scandinavia from Noponen et al. (1978):

\begin{tabular}{|c|c|c|c|c|c|c|c|c|c|}
\hline Year & Date & $\mathbf{h}$ & $\underset{\mathbf{m}}{\text { Time }}$ & $\mathbf{s}$ & $\begin{array}{l}\text { Latitude } \\
\mathrm{N}\end{array}$ & $\begin{array}{c}\text { Longitude } \\
\text { E }\end{array}$ & $\begin{array}{c}\text { Depth } \\
\text { km }\end{array}$ & Magnitude & Source \\
\hline 1929 & $23 \mathrm{MAY}$ & 18 & 36 & 24.6 & $57^{\circ} .18$ & $6^{\circ} .61$ & 0 & - & present author \\
\hline 1929 & $29 \mathrm{MAY}$ & 23 & 31 & 11.3 & $57^{\circ} .30$ & $6^{\circ} .35$ & 11 & - & present author \\
\hline 1954 & 18 OCT & 16 & 44 & 34.3 & $56^{\circ} .82$ & $8^{\circ} .26$ & 44 & - & present author \\
\hline 1964 & $14 \mathrm{JUL}$ & 05 & 33 & 56.7 & $57^{\circ} .03$ & $7^{\circ} .20$ & 36 & 4.4 & ISC \\
\hline 1966 & 9 FEB & 23 & 54 & 08.0 & $58^{\circ} .20$ & $9^{\circ} .10$ & 0 & - & ISC \\
\hline 1966 & 2 AUG & 06 & 53 & 35.0 & $58^{\circ} .20$ & $8^{\circ} .20$ & 0 & - & ISC \\
\hline 1967 & 12 APR & 09 & 09 & 25.0 & $58^{\circ} .10$ & $9^{\circ} .10$ & 0 & - & ISC \\
\hline 1968 & $18 \mathrm{JAN}$ & 12 & 54 & 55.0 & $58^{\circ} .00$ & $6^{\circ} .60$ & 0 & - & ISC \\
\hline 1968 & 29 APR & 21 & 59 & 21.0 & $58^{\circ} .00$ & $8^{\circ} .80$ & 0 & - & ISC \\
\hline 1969 & 5 APR & 19 & 09 & 48.3 & $57^{\circ} .13$ & $7^{\circ} .04$ & 33 & - & ISC \\
\hline 1969 & $21 \mathrm{OCT}$ & 19 & 58 & 40.0 & $57^{\circ} .30$ & $7^{\circ} .00$ & 0 & - & ISC \\
\hline 1970 & 19 MAR & 08 & 26 & 20.3 & $58^{\circ} 52$ & $10^{\circ} .40$ & 0 & - & ISC \\
\hline 1970 & $12 \mathrm{NOV}$ & 13 & 11 & 21.0 & $58^{\circ} .40$ & $6^{\circ} .00$ & $\mathbf{0}$ & - & ISC \\
\hline 1972 & $30 \mathrm{NOV}$ & 10 & 33 & 24.8 & $57^{\circ} .06$ & $7^{\circ} .18$ & 0 & - & ISC \\
\hline 1974 & 19 MAY & 15 & 56 & 49.8 & $56^{\circ} .44$ & $6^{\circ} .60$ & $\mathbf{0}$ & - & ISC \\
\hline 1974 & 16 OKT & 08 & 13 & 21.1 & $57^{\circ} .13$ & $7^{\circ} .24$ & 0 & - & ISC \\
\hline 1974 & $6 \mathrm{NOV}$ & 13 & 27 & 59.8 & $58^{\circ} .35$ & $6^{\circ} .99$ & 0 & - & ISC \\
\hline 1978 & $13 \mathrm{JAN}$ & 15 & 53 & 24.1 & $57^{\circ} .95$ & $8^{\circ} .53$ & 27 & approx. 3 & present author \\
\hline 1978 & $16 \mathrm{JAN}$ & 13 & 04 & 36.1 & $57^{\circ} .63$ & $7^{\circ} .75$ & 34 & approx. 3 & present author \\
\hline 1978 & 26 APR & 12 & 32 & 38.0 & $56^{\circ} .88$ & $7^{\circ} .80$ & 40 & approx. 4 & present author \\
\hline
\end{tabular}




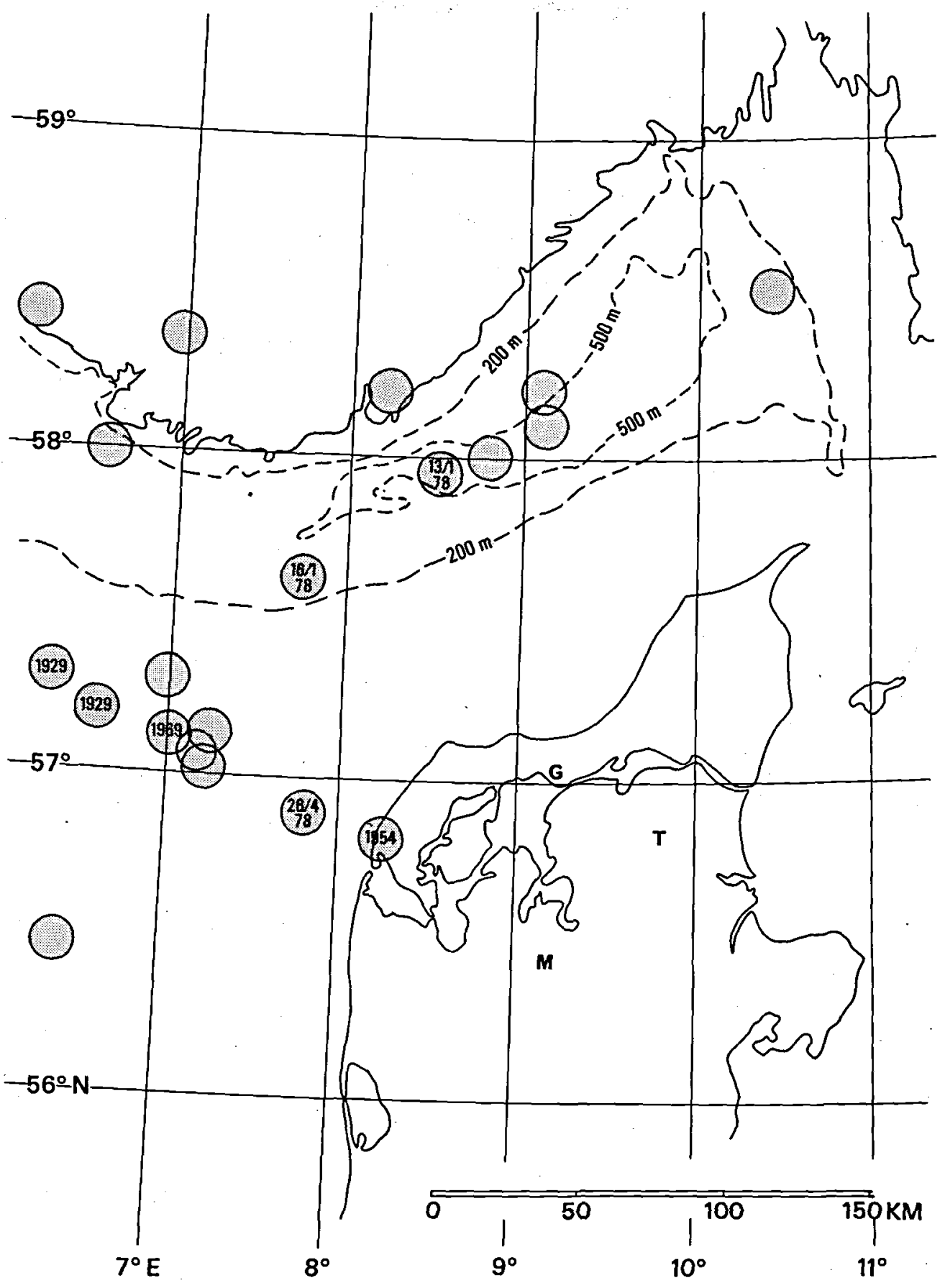

Figure 2. Epicenters for the earthquakes of table 1. All ISC locations for the period 1964-1974 and locations by the present author with date or year. $200 \mathrm{~m}$ and $500 \mathrm{~m}$ depth contours in the Norwegian Channel of the Skagerrak. $G, M$, and T indicate the locations of the seismographs in Gettrup, Mønsted and Thingbak respectively. 


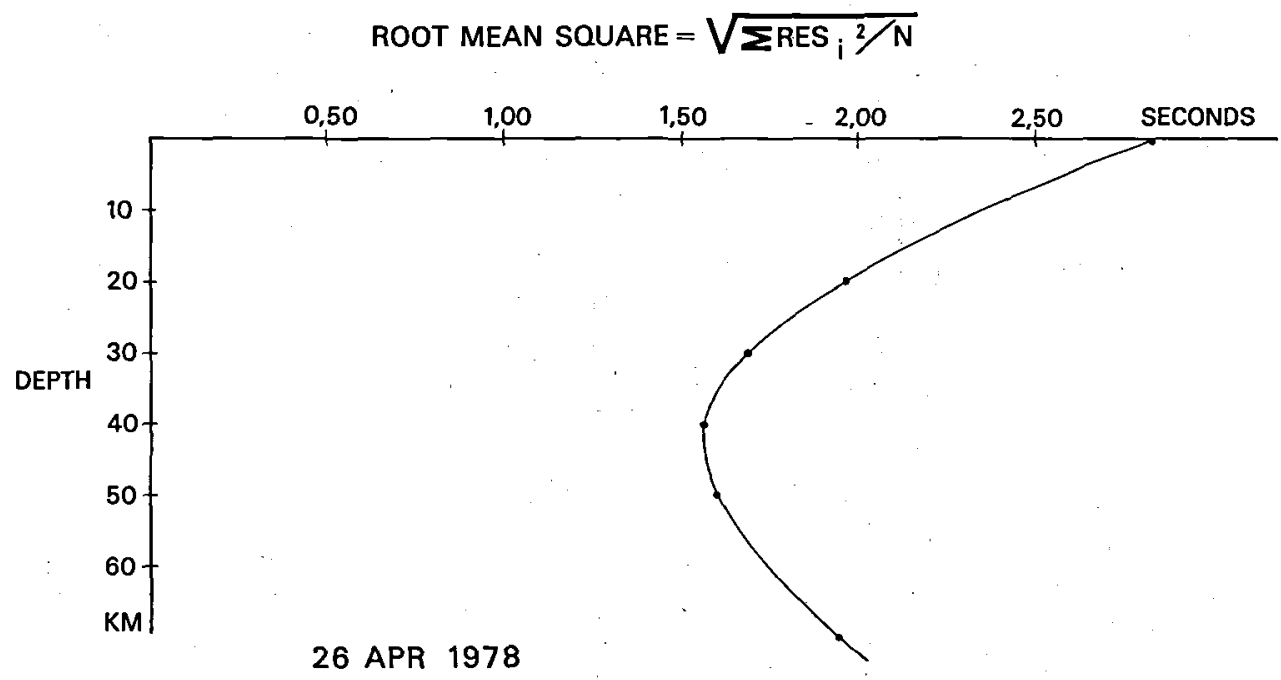

Figure 3. Root mean square for best fitting epicenter as a function of depth for the earthquake of 26 APR 1978. The root mean square is a measure of the misfit of the earthquake location to the data of the seismograms. The sum under the square root is over all ifrom 1 to $N$. $N$ is the number of observations.

All of the seismogram readings of the 1954 event have been reevaluated by the present author in the light of the comparison with the recent events. The reevaluated time differences between the seismogram readings at all of the stations that recorded the 1954 event fit quite well to the calculated time differences for the 1978 position. A new epicenter of the 1954 event has been calculated by the present author based on the reevaluated data (table 1 , fig. 2 ). The inaccuracy of the determined epicenter is such that it may be stated that the old and the new estimates of the epicenter of the 1954 event are close to each other, and that the 1954 event happened close to the location of the 1978 event (fig. 2). The 1978 location is one of the most accurate in the Skagerrak area, because of the near Jutland records.

A measure of the misfit between the observations and the calculations for the best fitting earthquake location is the sum of the squared residuals (expressed as root mean square in fig. 3), the residuals being the discrepancies between the observed arrival times of the seismic waves and the calculated arrival times. The depth dependence of the sum of the squared residuals for the 1978 event is illustrated in fig. 3. The curve has a minimum around $40 \mathrm{~km}$ depth, so a depth of $40 \mathrm{~km}$ is chosen for the earthquake. Fig. 3 is based on the seismogram readings of the near stations in Jutland, Copenhagen, Norway, Sweden and Scotland. The uncertainty of the $40 \mathrm{~km}$ depth of the earthquake probably is $10-20 \mathrm{~km}$.

The body wave magnitude of the 1969 earthquake was determined as 4.5 by the U.S. Coast and Geodetic Survey. The number of stations, on which this magnitude calculation is based, is so small that the International Seismological Centre did not report a magnitude. The presently investigated 1978 earthquake has a magnitude of approximately half a unit less than the 1969 earthquake, i.e. around 4.

Two even smaller earthquakes, of magnitudes around 3, have been recorded in northern Jutland by the temporary stations. The first one happened the 13th of January 1978. It has been plotted in fig. 2. It is seen to conform with the previously known pattern of seismicity. The depth is determined as $30 \mathrm{~km}$. The other small earthquake happened the 16th of January 1978. It was a multiple event, i.e. more than one rupture event took place in a fault zone. Four events can be distinguished in the seismograms within 33 seconds. The main shock is the last and largest of the 4 events. Three aftershocks followed this multiple event, presumably in the same place, approximately $5,6.5$ and 7 minutes after the main shock. The first events of the multiple event were so small that there is doubt whether the more distant stations in Norway and Sweden re- 
cord one or the other of the events as the first. As a consequence the uncertainties of the earthquake epicenter and the depth are larger than those of the events of 26 APR and 13 JAN 1978. Also this earthquake conforms with the previously known pattern of seismicity (fig. 2).

The earthquake bulletins of the University of Uppsala contain many more seismic events of small magnitude than those of table 1 , that fall in the Skagerrak and near the Norwegian coast. Some events are expected or known explosions others are expected to be earthquakes. The epicenters of those earthquakes are more uncertain than those illustrated in fig. 2, because of the distances from the Swedish stations. The depths of those earthquakes can not be determined, for the same reason. Approximately 90 seismic events within the area of fig. 2 have been reported by the University of Uppsala in the 11 year period from 1964-1974, which are not in table 1 and in fig. 2. In the same period other agencies reported 15 additional events in the area.

Previous to 1964 the International Seismological Centre did not exist and fewer stations were in operation in Scandinavia, so only the largest events, mainly those that were felt by people, have been reported. Lehmann (1956) has published a list of the earthquakes that were known to have happened before 1956 in or close to Denmark. Only three earthquakes before 1964 were large enough so that a sufficient number of seismological stations had recorded signals from them and a location could be recalculated by the present author. Of these three the 1954 event has already been mentioned. The epicenters of two earthquakes which happened in 1929, 23 MAY and 29 MAY, have also been recalculated by the present author. They have been included in table 1 and in fig. 2. The earthquakes were described by Lehmann (1929). The seismogram readings on which the calculations are based are published in the International Seismological Summary. An additional reading on the Copenhagen records of the seismic wave $\mathrm{Lg}$, which comes later than the $\mathrm{S}$ wave on the seismograms, has been done by the present author. The computer location program (Ward and Gregersen 1973) has been modified such that the $\mathrm{Lg}$ wave is taken into account. The trend in the seismicity in fig. 2 through the 1929 epicenters SE toward the coast of Jutland may not be real. The 1929 epicenters are more uncertain than the other epicenters so they may coincide with the group of epicenters around the 1969 epicenter, and the 1954 epicenter may not be really different from the 1978 epicenter. It is argued though in this paper that the 1978 and the 1969 epicenters are different.

A seismic trend along the Norwegian Channel suggested previously from the data of the International Seismological Centre and the University of Uppsala is confirmed by the data of this paper. The earthquakes in the Skagerrak seem to happen typically close to the base of the earths crust at depths of $30-40 \mathrm{~km}$.

Acknowledgments. The valuable assistance by many persons is appreciated. H. Kold, H. C. Kold, A. Sørensen, H. Nielsen, T. Dahl Jensen and P. Poulsen operated the seismographs in Jutland. H. P. Rasmussen took part in the inspection and repair work. J. Hjelme and $\mathrm{E}$. Hjortenberg suggested improvements to the manuscript and L. Montad typed it.

\section{Dansk sammendrag}

I lobet af vinteren 1977-1978 har op til 3 seismografer varet midlertidigt placeret $\mathrm{i}$ den nordlige del af Jylland med det formål at registrere nære jordskalv. 3 jordrystelser, formodentlig jordskælv, er blevet registreret af 1, 2 eller 3 af disse seismografter. Et af jordskalvene var stort nok til en speciel undersøgelse. Dette jordskælvs position er ganske nær ved Jyllands kyst, medens de to mindre jordskælvs positioner er $i$ Norskerenden i Skagerrak, hvor et antal tidligere jordskalv vides at være sket. Dybden af det største af jordskalvene er $\mathbf{4 0}$ $\mathrm{km}$. Dette dybdeskøn er mere nøjagtigt end noget tidligere skøn på grund af de nare seismiske stationer, der registrerede jordskælvet.

\section{References}

Lehmann, I. 1929: Jordskälvet i Jylland den 23. maj 1929. Naturens Verden: 307-315.

Lehmann, I. 1956: Danske jordskalv. Meddr dansk geol. Foren., 13: 88-103.

Noponen, I., Pelkonen, E., Mustila, L. \& Raime, M. 1978 Seismic Events in Northerm Europe January-February 1977 and a description of the procedure of locating them. Institute of Seismology, University of Helsinki, Helsinki.

Saxov, S. 1956: Some Gravity Measurements in Thy, Mors, and Vendsyssel. Geodatisk Instituts Skrifter 3. Rakke, 25: 46 pp.

Ward, P. L. \& Gregersen, S. 1973: Comparison of Earthquake Locations determined with data from a Network of Stations and Small Tripartite Arrays on Kilauea Volcano, Hawaii. Bull. Seism. Soc. Am., 63: 679-711. 